\title{
4.11 Академічна етика як фундаментальна цінність освіти
}

Тема академічної доброчесності сьогодні $є$ досить актуальною на українському освітньому просторі, оскільки шлях до європейського суспільства потребує фахівців, що отримали у вишах не лише професійні знання, але й знання про закони, загальноприйнятні етичні правила і норми, що забезпечують академічну доброчесність як основний принцип академічного життя.

Під терміном «академічна доброчесність» прийнято розуміти сукупність моральних цінностей, таких як чесність, довіра, повага, справедливість, відповідальність.

Саме такі етичні стандарти, що мають впливати не лише на науковий розвиток академічної спільноти, але й допоможуть у формуванні моральності суспільства в цілому, закріплені в Бухарестській Декларації з етичних цінностей та принципів вищої освіти в Свропейському регіоні [361]. У другому розділі Декларації «Цінності та принципи», задекларовані ключові цінності академічної доброчесності та принципи їх втілення в освітній процес. Зокрема, зазначено, що «виховання чесності слід починати з себе, а вже потім домагатися іiї поширення серед всіх членів академічної спільноти, не допускаючи ніяких форм обману, брехні, шахрайства, крадіжки або інших форм нечесної поведінки, які негативно впливають на якість отриманих академічних ступенів».

В Декларації зазначається, що забезпечення справедливості у викладанні, оцінюванні освітніх досягнень студентів наукових дослідженнях, кар'єрному просуванні персоналу, отриманні будь-яких нагород, відзнак, ступенів повинно грунтуватися на законних, справедливих, передбачуваних, послідовних i об'єктивних критеріях. Особлива увага в документі привертається до довіри та відповідальності всіх членів академічної спільноти, як до підгрунтя існування науки в Україні, запоруки іï розвитку. В першу чергу це стосується закладів освіти, оскільки їх особливим призначенням $є$ підготовка вмотивованих на академічну доброчесність фахівців, від яких залежить подальший розвиток нашої країни. Однак, на жаль, велика частка здобувачів вищої освіти 
мотивована не стільки на отримання та розвиток знань, скільки на такі атрибути вищої освіти, як бали, стипендія, диплом. Така ситуація має транзитивний характер, складаючись ще в період отримання освіти у закладах загальної середньої освіти, тому впровадження принципів академічної доброчесності необхідно починати ще зі шкільної лави, роз’яснюючи учням зміст нормативних категорій, прописаних у вітчизняному законодавстві та міжнародних правових документах. Перш за все, необхідно роз'яснювати статті Української Конституції, що стосуються захисту результатів інтелектуальної та творчої діяльності. Так, стаття 41 діючої Конституції України закріплює право «володіти, користуватися і розпоряджатися своєю власністю, результатами своєї інтелектуальної, творчої діяльності» [362, с. 45]. Стаття 54 гарантує громадянам України свободу «літературної, художньої, наукової і технічної творчості, захист інтелектуальної власності, авторських прав, моральних і матеріальних інтересів, що виникають у зв'язку з різними видами інтелектуальної діяльності». [362, с. 59].

XX1 ст. стало часом радикальних трансформацій української системи освіти. Такі фактори, як розвиток нових інформаційно-комунікаційних технологій та створення на їх основі міжнародної мережі знань, зростання соціальної мобільності студентської молоді, певним чином спровокували зниження академічних стандартів вищої школи, навіть, їх деформацію. Інтелектуальне запозичення торкнулося всіх рівнів науково-освітнього процесу, починаючи 3 середньої школи i закінчуючи професорсько-викладацьким складом будь-якого вишу [364].

Чітке визначення поняття академічної доброчесності закріплене в рамковому законі «Про освіту». Відповідно до 42 статті цього Закону академічна доброчесність - це сукупність етичних принципів та визначених законом правил, якими мають керуватися учасники освітнього процесу під час навчання, викладання та провадження наукової (творчої) діяльності з метою забезпечення довіри до результатів навчання та/або наукових (творчих) досягнень [365]. Як бачимо, академічна доброчесність це, з одного 
боку, «сукупність етичних принципів», а 3 іншого - сукупність чітких, «визначених законом правил». Тобто має місце поєднання ціннісних складових з їх практичним значенням та застосуванням.

Нормативно-правове забезпечення впровадження принципів академічної доброчесності у вищих навчальних закладах регламентується Законами України «Про освіту», «Про вищу освіту», «Про наукову та технічну діяльність».

Закон України «Про вищу освіту» [366] вимагає від всіх учасників освітнього процесу дотримання у своїй діяльності правил, визначених Законом «Про освіту», що допоможе протистояти академічній недоброчесності в освіті.

Треба зазначити, що поширення різних форм академічної недоброчесності не $\epsilon$ суто вітчизняною проблемою, це світова тенденція, викликана розвитком інформаційних технологій, легкістю доступу до інформації в мережі інтернет (інтернет-плагіат). 3 кожним роком ця проблема стає все більш глобальною. Сьогодні до прояву академічної недоброчесності відносяться використання абро дублювання інформації, результатів досліджень; посилання на джерела, які не використовувалися в роботі; надання допомоги для здійснення акту академічної нечесності - навмисна чи усвідомлена допомога або спроба допомогти іншому вчинити акт академічної нечесності; придбання в інших осіб чи організацій 3 наступним подання як власних результатів діяльності [367, с.22-26].

Міжнародною академічною спільнотою сформульовані та визнані загальні критерії академічної доброчесності, такі як: чесність, відповідальність, повага до інтелектуальної власності та авторських прав на неї, добросовісність, прозорість тощо. Незважаючи на певну розмитість та розпливчастість цих понять, є зрозумілим що норми права і норми моралі взаємопов'язані i виступають підгрунтям якісної освіти.

Для підтримки співробітництва вищих учбових закладів в галузі академічної чесності були створені та функціонують такі міжнародні організації, як «Міжнародний центр академічної чесності ("The International Center for Academic Integrity" (ICAI) та «Свропейська мережа академічної чесності ("European Network for Academic Integrity"). 
В Україні задля вирішення цих проблем було створено Проект сприяння академічній доброчесності (Strengthening Academic Integrity in Ukraine Project SAIUP). Цей проект є ініціативою Американських Рад 3 міжнародної освіти за сприяння Міністерства освіти і науки України, спрямованою на системні зміни в українській вищій освіті, покращення іміджу українських вишів. Метою проекту є підтримка стійких змін в освіті України, формування академічної доброчесності як важливої складової трансформації української освітньої системи.

Пошук шляхів підвищення академічної доброчесності в освітній спільноті $€$ предметом наукових досліджень та дискусій в Україні. Аналіз робіт, що присвячені цій проблемі показує, що вітчизняними дослідниками багато уваги приділяється етиці чеснот. Так, Н. Бойченко зауважує, що бурхливий розвиток наукового знання висуває перед вченими низку етичних проблем і вимагає їх дотримання. «Наукова діяльність не може бути нейтральною в етичному плані, етика повинна бути невід'ємною складовою підготовки кожного фахівця» [368].

На думку С. Мовчана важливим i, навіть, необхідним є "усвідомлення науковцями себе як певної духовної спільноти» [369, с. 398]. Автор звертає увагу на запропонований К. Поппером підхід до процесу творення достовірності знання внаслідок складності його перевірки, і вважає, що наукова спільнота має виступати носієм морально-ціннісного відношення до змісту знання та процесу його творення.

На важливості формування етичного аспекту поведінки вченого наполягає В. О. Зінченко [370].

Автори колективного наукового дослідження 3 проблем дотримання академічної доброчесності, здійсненого за науковою редакцією Н. Сорокіної, значну увагу приділяють академічній доброчесності як основі сталого розвитку університетів [371].

3 точки зору постановки етичних проблем в академічній сфері, заслуговують на увагу роботи І. Тодорової [372]. А. Колєснікова[373]. 
Більшість дослідників вважають, що науковий процес, як і будь-яка сфера діяльності, пов'язаний з моральними, етичними аспектами і мета освітньої та наукової діяльності може бути досягнена лише в тому середовищі, де підтримуються стандарти етики. Дотримання цих стандартів в освітній діяльності передбачає перш за все дотримання педагогічними, науковопедагогічними працівниками та здобувачами освіти принципів академічної доброчесності.

Неможна залишити поза увагою проголошення у 2009 році Етичного кодексу вченого України [374]. Кодекс наголошує, що кожна практика має свої правила, однак, ці правила не повинні виходити за межі етичних цінностей науки, вони повинні забезпечувати відкритість і чесність будь-яких наукових досліджень, концептуалізувати освіту як поширення академічних чеснот на всі інші суспільні взаємини.

Практичне втілення етики чеснот науково-педагогічними працівниками передбачає дотримання таких норм, як дотримання законодавства про авторське право і суміжні права, надання достовірної інформації про методики та результати досліджень, контроль за дотриманням академічної доброчесності здобувачами освіти, посилання на джерела інформації у разі використання ідей.

Науково-педагогічні працівники повинні озвучувати етичні чесноти, робити їх частиною діалогу зі студентами, використовувати потенціал етичних цінностей в контексті інформування щодо різних аспектів життя в університетському середовищі та поза його межами, адже навчальні заклади повинні виконувати не лише освітні завдання. Не менш важливим $є$ й завдання виховання поваги до загальноприйнятих етичних правил та норм. Саме тому академічна доброчесність має фундаментальне значення і повинна стати основним принципом академічного життя.

Заклади вищої освіти мають затверджувати правила та норми поведінки, які містять такі елементи, як: законність, етичність, рівність, прозорість, незалежність, взаємодовіра, толерантність[375]. . 
Дотримання цих принципів залежить від усіх учасників освітнього процесу. Зміст політики і правил академічної доброчесності має бути донесений до кожного учасника. Студентам мають бути доступні консультації з питань академічного письма, уникнення порушень академічної доброчесності, процедур розгляду таких порушень, можливих видів академічної відповідальності. Дуже важливо, щоб заклади вищої освіти мали можливість створювати власну політику у сфері академічної доброчесності, власні документи, кодекси етики, курси академічного письма тощо. Всі ці речі, на думку голови Національного агентства із забезпечення якості вищої освіти С. Квита, - важать набагато більше для розвитку академічної доброчесності, ніж покарання за порушення[376].

Розвиток академічної етики - це основний засіб, за допомогою якого університети можуть робити реальний внесок у побудову цивілізованого суспільства. Тому університети, як і інші освітні установи, часто є останнім шансом на подолання «кризи порядності» i, отже, несуть особливу відповідальність. Адже зрозуміло, що якщо звички порядності не будуть щеплені студентам, перш ніж вони закінчать навчальні заклади і підуть працювати, то дуже малоймовірно, що ці звички зможуть бути розвинені в них пізніше[377].

Будь-яка студентська робота $є$ демонстрацією наявності та ступеня сформованості академічної етики. Тому необхідно навчати студентів працювати 3 інформацією, формувати у них цілісну систему цінностей і норм академічної етики, звичку до академічної сумлінності, до етичного використання інформації. Під рівнем академічної сумлінності мається на увазі свідома відмова студентів від академічного шахрайства (чесне виконання робіт, дотримання авторських прав, самостійність у наукових дослідженнях, відмова від списування, плагіату, коректне використання запозиченої інформації).

Визначення власних моральних стандартів, їх зіставлення з найкращими зразками академічної культури, втілення у життя у всіх напрямках роботи вищого навчального закладу $є$ проявом прагнення вітчизняної освітньої спільноти взяти на себе відповідальність у захисті норм права та базових 
академічних та моральних цінностей, забезпечення якості та результатів навчання. Тому сьогодні особливо актуальною стає проблема соціальнопрофесійного становлення студентів через поширення доброчесності в академічному середовищі України та ії̈ вплив на весь академічний простір.

Система академічної доброчесності в закладах вищої освіти є постійно діючим процесом над яким потрібно працювати усім учасникам освітнього процесу та удосконалювати механізми ефективної взаємодії. 